Brief Report

\title{
First report and comparative genomics analysis of a bla oxA- 244-harbouring Escherichia coli isolate recovered in American continent.
}

Deisy J Abril1, Ingrid Gisell Bustos Moya², Ricaurte Alejandro Marquez-Ortiz¹, Diego Fernando Josa

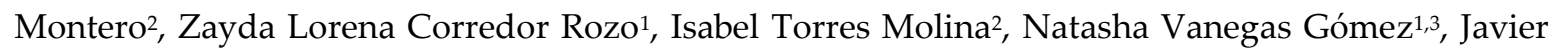
Escobar-Perez ${ }^{1 *}$

1. Bacterial Molecular Genetics Laboratory, Universidad El Bosque, Bogotá D.C., Colombia.

2. Grupo de Medicina Cardiovascular y especialidades de alta complejidad - Fundación Clínica Shaio, Bogotá D.C., Colombia.

3. The i3 institute, Faculty of Science University of Technology, Sydney, Australia.

Correspondence: Javier Escobar Pérez, escobarjavier@unbosque.edu.co, ORCID number: 0000-0002-0432-6978

\begin{abstract}
The carbapenemase OXA-244 is a derivate of OXA-48, and its detection is very difficult in laboratories. Here we report the identification and genomic analysis of an Escherichia coli isolate (28Eco12) harbouring the blaoxA-244 gene identified in Colombia, South America.

The 28Eco12 isolate was identified during a retrospective study and it was recovered from a patient treated in Colombia. The complete nucleotide sequence was established using the PacBio platform. A comparative genomics analysis with other blaoxA-244-harbouring Escherichia coli strains was performed. The 28Eco12 isolate belonged to sequence type (ST) 38 and its genome was composed of two molecules, a chromosome of 5,343,367 bp and a plasmid of 92,027 bp, which belonged to the incompatibility group IncY and did not harbour resistance genes. The blaoxA-244 gene was chromosomally-encoded and mobilized by an ISR1-related Tn6237 composite transposon. Notably, this transposon was inserted and located within a new genomic island. For our knowledge this is the first report of a blaOXA-244-harbouring Escherichia coli isolate in American continent.

Our results suggest that the introduction of the OXA-244-producing E. coli isolate was through clonal expansion of the ST38 pandemic clone. Other isolates producing OXA-244 could be circulating silently on the American continent.
\end{abstract}

Keywords: blaoXA-244; Escherichia coli; Carbapenems; Resistance; Colombia. 
$\mathbf{2}$ de 11

21

22

23

24

25

26

27

28

29

30

31

32

33

34

35

36

37

38

39

40

41

42

43

44

45

46

47

48

49

50

51

52

53

54

55

56

57

58

59

60

\section{Introduction}

The WHO has recognized carbapenem-resistant Enterobacteriaceae as pathogens with critical priority for the development of new antibiotics [1]. OXA-244 is a carbapenemase belonging to the Class D family, is a derivate of OXA-48, and is encoded by the blaoxA-244 gene. Although there are multiple reports of OXA-48-producing isolates, reports of isolates harbouring OXA-244 are less frequent, perhaps as their detection is difficult due to their reduced carbapenem activity. The blaoxA${ }_{244}$ gene was initially described in 2011, within a Klebsiella pneumoniae isolate, identified in Spain [2]. It has already been identified in Escherichia coli isolates recovered from Germany [3], France [4,5], the United Kingdom [6], South East Asia [7], and Egypt [5]. The molecular characterization of some of these E. coli isolates have shown that the majority of them belong to sequence type (ST) 38, although recently other STs have been found (ST361, ST1722, and ST3541) [5]; and contain other $\beta$ lactamases such as TEM, CTX-M and CMY. The blaoxA-244 gene is located in the chromosome within a truncated Tn1999.2 transposon, which is immersed into an ISR1-based Tn6237 transposon [4,8]. Here, we provide a genomic analysis of an Escherichia coli isolate (28Eco12) contained the blaoxA-244 gene recovered from a patient in Colombia, South America. For our knowledge this is the first report of a blaoxA-244-harbouring Escherichia coli isolate in American continent.

\section{Results}

The 28Eco12 isolate was identified from a retrospective study in Bogotá, Colombia (see Materials and Methods) and we decided to establish its complete genome to determine its resistome and mobile genetic platform distribution (IS content). The genome was composed of two molecules, a chromosome of 5,343,367 bp and a plasmid of 92,027 bp, which did not harbour resistance genes and belonged to the incompatibility group IncY. The resistance genes arsenal of the isolate was composed of aph(3")-Ib, aph(6)-Id, aaaA1 (aminoglycosides), blaохA-244, blactX-M-14b, blaтем-1b (betalactams), catA1 (chloramphenicol), sul2 (sulphonamides), dfrA1 (trimethoprim), and tetD (tetracycline) genes, all chromosomally-encoded (Figure 1). The 28Eco12 isolate belonged to ST38 [9]. The "in silico" serotyping of the isolate was O102:H6.

Using the complete genome sequence, the 28Eco12 isolate was found to have a close genetic relationship with the E. coli strain 266917_2 (ST38), described recently in the United Kingdom (90\% coverage, 97\% identity, GenBank accession number CP026723.1), which does not contain the blaoxA244 gene. The genomic comparative analysis revealed that the blaoxA-244 gene was mobilized by the Tn6237 transposon, as it has previously been described in Escherichia coli strain VAL [4,8]. However, in the 28Eco12 isolate, the Tn6237 transposon was not inserted within the II536 pathogenicity island, as was previously reported to blaOxA-48 [8], but into a new putative genomic island, inserted within the $t R N A$-sec gene. Its insertion produced a $39 \mathrm{bp}$ direct repeat sequence (TTCGACTCCTGTGATCTTCCGCCAATTAACATCTTCTGA). This event did not change the $t R N A$-sec gene sequence (Figure 2). 


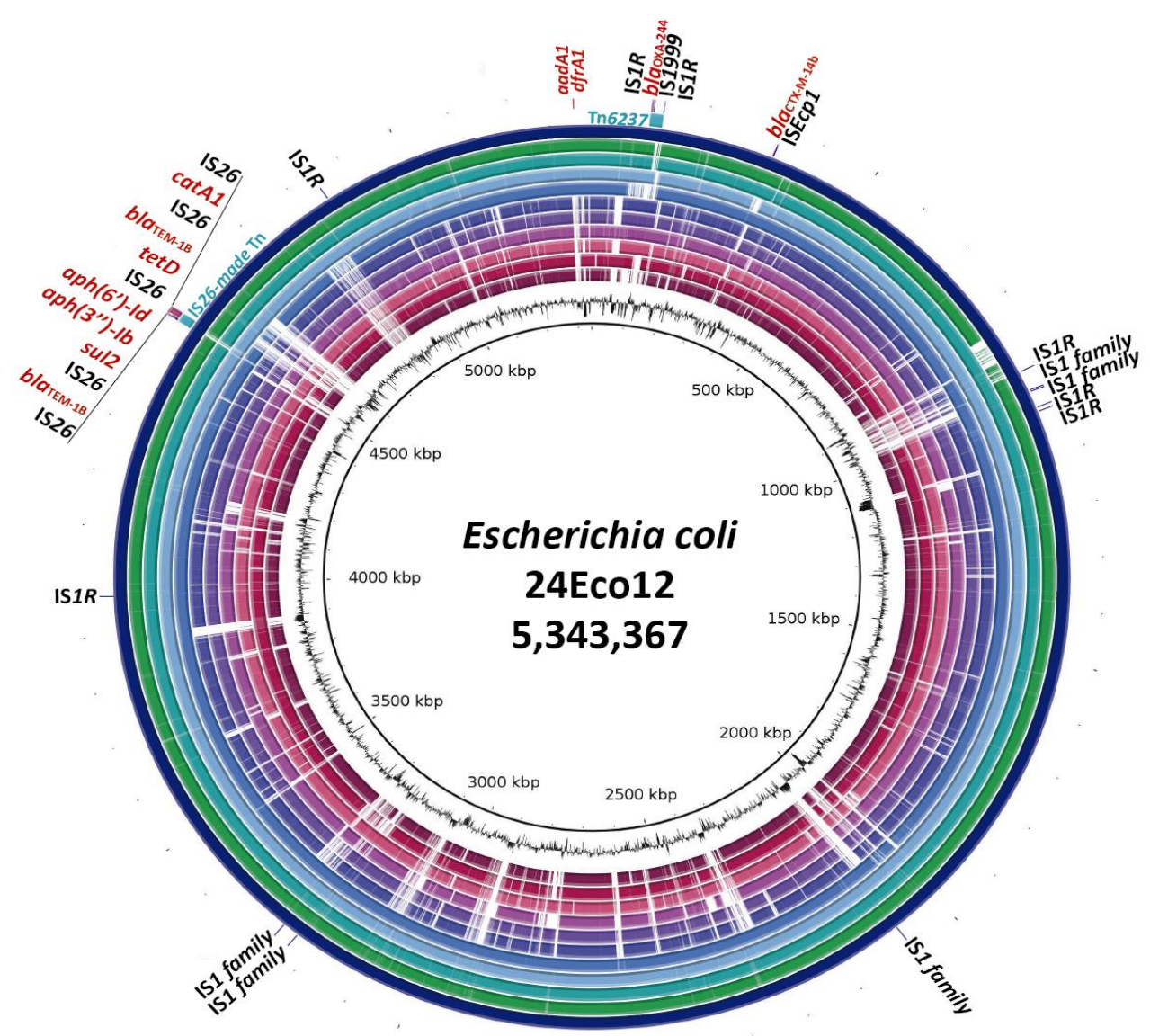

Figure 1. BLASTn comparison of the blaoxA-244-containing Escherichia coli chromosomes. The K-12, F8111-1SC3 and 266917_2 strains were used as reference. At the more external circle is shown the localization of the resistance genes and their putative genetic platforms of mobilization. The positions of the seven identical ISR1 and five IS1-family ( $>89 \%$ of identity) sequences are also indicated. The strain positions on the figure are as follow (internal to external) (sequence type/serotype): K12 (ST10/O16:H48), F8111-1SC3 (ST182/O169:H41), 86J1 (ST361/O9:H30), 62D3 (ST1722/O1:H25), 85H4 (ST3541/O53:H18), 73G4 (ST3541/O53:H18), 266917_2 (ST38/O51:H30), 35J9 (ST38/O102:H6), 69E6 (ST38/O102:H6), 78B5 (ST38/O102:H6) and 28Eco12 (ST38/O102:H6).

The putative island was also present in the blaoxA-244-negative enterotoxigenic E. coli F8111-1SC3 isolate (GenBank accession number NZ_CP024269.1). Interestingly, the $t R N A$-sec gene is a hot spot for DNA insertion because it also serves as the insertion site of the I536 pathogenicity island in the uropathogenic strain E. coli 536 [10]. These results suggest that the Tn6237 transposon is active, and moves to different sites in the E. coli chromosome. In addition, the isolate harboured 69 ISs belonging to 17 different IS families (Table 1). Some of these present as single copy, partial form or multiple copies. The most frequent IS families were IS1, IS200/IS605_ssgr_IS200, and IS3 with 13, 10, and 8 IS copies, respectively. Target Site Duplications (TSD) are signatures of transposition events and among the 69 ISs, 25 presented TSDs and none were present within the E. coli F8111-1SC3 
4 de 11

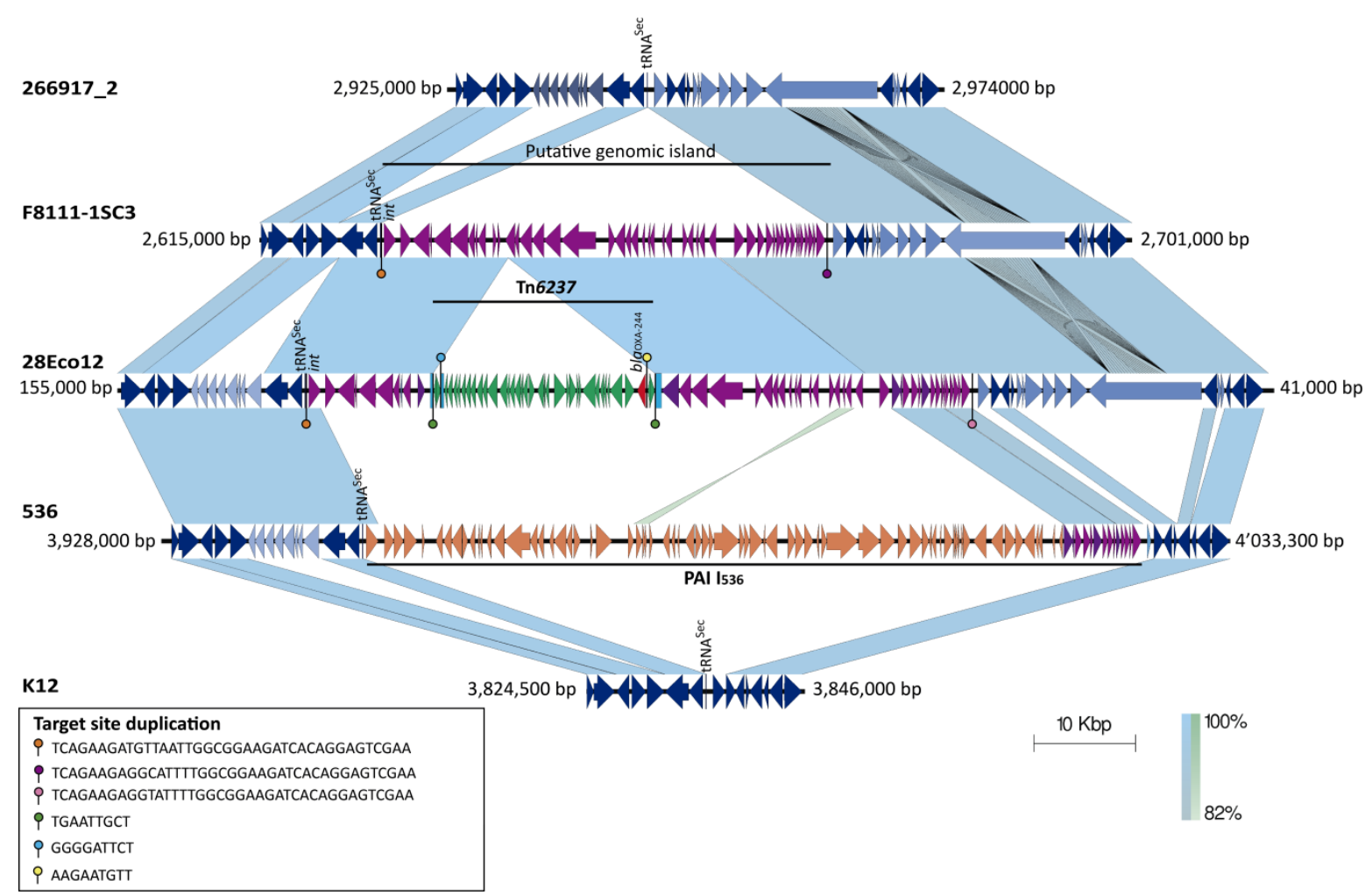

Figure 2. Comparison of the region where the blaOxA-244 gene was inserted within Escherichia coli 28 Eco12 isolate. The red arrow corresponds to the blaoxA-244 gene. The mobile genetics elements are shown in different colors. The putative genomic island is shown in purple and its insertion within the $t R N A$-sec gene is indicated respect to the E. coli strain 266917_2 (GenBank accession number CP026723.1). The blue rectangles correspond to the gene where the Tn6237 transposon was inserted (green arrows). The pallets represent the target site duplications. The int gene that encodes the phage integrase protein is shown. Blue shading between pairs of sequences indicates $>90 \%$ of identity in a window of $400 \mathrm{bp}$. The scale bar indicates sequence length.

isolate indicating that were inserted by single copy transposition. The TSD pattern analysis also revealed the presence of two composite transposons, the Tn6237 (mentioned previously) and a 15,730 bp IS26-made transposon, which was inserted within a gene that encodes a hypothetical protein and mobilizes the aph(3")-Ib, aph(6)-Id, blaTEM-1b (two copies), catA1, sul2, and tetD genes. Notably, this IS26 transposon was also inserted within another putative genomic island, which was inserted into the $t R N A$-leu gene. The comparative analysis suggested that this IS26 transposon was mobilized from a plasmid because it harboured the repA gene that corresponds to the incompatibility group IncQ-1 and possesses DNA fragments with a high percentage of identity to pD90-1 and pEC141 plasmids, which were identified in mor-1-containing Salmonella enterica and E. coli strains, respectively [11]. With respect to the other resistance genes, the blactx-m gene was mobilized by ISEcp1 and an IS26 remnant, which were inserted within a gene that encodes a hypothetical protein. 
5 de 11

103 Table 1. Insertion sequences identified in 28Eco12 isolate. Target Site Duplications (TSD) are showed in bold 104 and underlined. In addition, the TSD of the composite transposons are colored.

\begin{tabular}{|c|c|c|c|c|c|}
\hline $\begin{array}{c}\text { IS } \\
\text { family }\end{array}$ & \multirow{2}{*}{$\begin{array}{c}\text { IS } \\
\text { IS1R }\end{array}$} & \multirow{2}{*}{$\begin{array}{c}\text { Position } \\
102025 . .102792\end{array}$} & \multicolumn{2}{|c|}{$\begin{array}{l}\text { Right and left flanking } \\
\text { sequences }\end{array}$} & \multirow{3}{*}{$\begin{array}{c}\text { Comments } \\
\text { Composite transposon harboring } \\
\text { the blaoxA-244 gene. }\end{array}$} \\
\hline \multirow{13}{*}{ IS1 } & & & $\underline{\text { TGAATTGCT }}$ & AAGAATGTT & \\
\hline & IS1R & $123120 . .123887$ & GGGGATTCT & TGAATTGCT & \\
\hline & IS1R & $936063 . .936830$ & $\frac{\text { CAGACAAC }}{\underline{\mathrm{G}}}$ & $\frac{\text { CAGACAAC }}{\underline{\mathrm{G}}}$ & $\begin{array}{c}\text { Single IS transposition. IS } \\
\text { inserted within a putative } \\
\text { prophage }\end{array}$ \\
\hline & IS1-like & $975280 . .976060$ & GTCGCAACC & TACAACGTT & $\begin{array}{l}\text { IS inserted within a putative } \\
\text { prophage }\end{array}$ \\
\hline & IS1-like & $977300 . .978080$ & GACAATGTC & CAATCTGCT & $\begin{array}{l}\text { IS inserted within a putative } \\
\text { prophage }\end{array}$ \\
\hline & IS1R & $1007836 . .1008603$ & $\underline{\text { TGCTTTTCT }}$ & $\underline{\text { TGCTTTTCT }}$ & $\begin{array}{c}\text { Single IS transposition. IS } \\
\text { inserted within a intergenic } \\
\text { region }\end{array}$ \\
\hline & IS1R & 1015519..1016286 & $\frac{\text { GCCAATTC }}{\underline{\mathrm{G}}}$ & $\frac{\text { GCCAATTC }}{\underline{\mathrm{G}}}$ & $\begin{array}{c}\text { Single IS transposition. IS } \\
\text { inserted within the } c m t B \text { gene }\end{array}$ \\
\hline & IS1-like & 2087231.. 2087998 & CGGTTTTGG & GAAGAGTTC & IS inserted within the $h c h A$ gene \\
\hline & IS1-like & $3237236 . .3237910$ & - & GAAATCCСC & $\begin{array}{l}\text { IS (truncated) inserted within a } \\
\text { putative prophage }\end{array}$ \\
\hline & IS1-like & $3266386 . .3267153$ & CTGCAAATC & TACAACCGG & $\begin{array}{l}\text { IS inserted within a putative } \\
\text { prophage }\end{array}$ \\
\hline & IS1R & $3972674 . .3973441$ & CTGCTCCTG & $\underline{\text { CTGCTCCTG }}$ & $\begin{array}{c}\text { Single IS transposition. IS } \\
\text { inserted within a hypothetical } \\
\text { gene }\end{array}$ \\
\hline & IS1R & $4845817 . .4846584$ & GACGGTATT & CGGATGCTG & IS inserted within the adiA gene \\
\hline & IS1H & $5066636 . .5067399$ & CCGGTAAAC & CTTCTGATG & $\begin{array}{c}\text { IS inserted within a intergenic } \\
\text { region }\end{array}$ \\
\hline \multirow{10}{*}{$\begin{array}{l}\text { IS200/ } \\
\text { IS605_s } \\
\text { sgr_IS2 } \\
00\end{array}$} & IS200C & $1127230 . .1127936$ & $\underline{\text { TTTT }}$ & $\underline{\text { TTTT }}$ & $\begin{array}{l}\text { Single IS transposition. IS } \\
\text { inserted within a T rich region }\end{array}$ \\
\hline & IS200C & 1690413..1691121 & $\underline{\text { TTTT }}$ & $\underline{\text { TTTT }}$ & $\begin{array}{l}\text { Single IS transposition. IS } \\
\text { inserted within a T rich region }\end{array}$ \\
\hline & IS200C & $2442570 . .2443280$ & $\underline{\text { TTAA }}$ & $\underline{\text { TTAA }}$ & $\begin{array}{l}\text { Single IS transposition. IS } \\
\text { inserted within a T rich region }\end{array}$ \\
\hline & IS200C & $2481694 . .2482403$ & TTTT & $\underline{\text { TTAT }}$ & $\begin{array}{c}\text { Single IS transposition. IS } \\
\text { inserted within a T rich region }\end{array}$ \\
\hline & IS200C & $2990220 . .2990930$ & $\underline{\text { AAAA }}$ & $\underline{\text { AAAA }}$ & $\begin{array}{l}\text { Single IS transposition. IS } \\
\text { inserted within a T rich region }\end{array}$ \\
\hline & IS200C & $3058643 . .3059351$ & $\underline{\text { TAAA }}$ & $\underline{\text { AAAA }}$ & $\begin{array}{l}\text { Single IS transposition. IS } \\
\text { inserted within a T rich region }\end{array}$ \\
\hline & IS200C & $3060222 . .3060929$ & $\underline{\text { AAAA }}$ & $\underline{\text { AAAA }}$ & $\begin{array}{l}\text { Single IS transposition. IS } \\
\text { inserted within a T rich region }\end{array}$ \\
\hline & IS200C & $3271558 . .3272271$ & GCAA & AAAA & $\begin{array}{l}\text { IS inserted within a putative } \\
\text { prophage }\end{array}$ \\
\hline & IS200C & $3939865 . .3940573$ & $\underline{\text { CAAA }}$ & $\underline{\text { AAAA }}$ & $\begin{array}{l}\text { Single IS transposition. IS } \\
\text { inserted within a T rich region }\end{array}$ \\
\hline & IS200C & 3994005..3994713 & $\underline{\mathbf{A A A A}}$ & $\underline{\mathbf{A A A A}}$ & Single IS transposition. IS \\
\hline
\end{tabular}


6 de 11

inserted within a $\mathrm{T}$ rich region

\begin{tabular}{|c|c|c|c|c|c|}
\hline \multirow{8}{*}{ IS3 } & IS600 & $3254256 . .3255501$ & CAA & ACA & $\begin{array}{l}\text { IS inserted within a genomic } \\
\text { island }\end{array}$ \\
\hline & ISSd1 & $949559 . .950499$ & CAGTT & - & $\begin{array}{l}\text { IS (truncated) inserted within a } \\
\text { putative prophage }\end{array}$ \\
\hline & ISSd1 & $3267154 . .3267978$ & - & GGT & $\begin{array}{l}\text { IS (truncated) inserted within a } \\
\text { genomic island }\end{array}$ \\
\hline & ISSfl10 & $951719 . .952045$ & - & GTT & $\begin{array}{l}\text { IS (truncated) inserted within a } \\
\text { putative prophage }\end{array}$ \\
\hline & IS3 & $3259199 . .3260456$ & TCAT & TTTA & $\begin{array}{l}\text { IS inserted within a genomic } \\
\text { island }\end{array}$ \\
\hline & IS3 & $3236998 . .3237235$ & - & СТTC & $\begin{array}{l}\text { IS (truncated) inserted within a } \\
\text { genomic island }\end{array}$ \\
\hline & ISEc52 & $3249338 . .3250086$ & - & - & $\begin{array}{l}\text { IS (truncated) inserted within a } \\
\text { genomic island }\end{array}$ \\
\hline & ISEc52 & $3246586 . .3247067$ & - & - & $\begin{array}{l}\text { IS (truncated) inserted within a } \\
\text { genomic island }\end{array}$ \\
\hline \multirow{6}{*}{ ISAs1 } & ISEc1 & $369367 . .369900$ & - & СССТ & $\begin{array}{l}\text { IS (truncated, formerly Rhs - } \\
\text { Rearrangement hot spots- } \\
\text { element) }\end{array}$ \\
\hline & ISEc1 & $2456311 . .2456957$ & GATC & - & $\begin{array}{l}\text { IS (truncated, formerly Rhs - } \\
\text { Rearrangement hot spots- } \\
\text { element) }\end{array}$ \\
\hline & ISEc1 & $3675287 . .3676199$ & TGTTGTAG & TCCTTGGC & $\begin{array}{c}\text { IS (formerly Rhs -Rearrangement } \\
\text { hot spots- element) }\end{array}$ \\
\hline & ISEc1 & $3815490 . .3816780$ & GATGTATA & CCTGCTCA & $\begin{array}{c}\text { IS (formerly Rhs -Rearrangement } \\
\text { hot spots- element) }\end{array}$ \\
\hline & ISEc1 & $4160599 . .4161889$ & ТТССТТСС & САСТTCAC & $\begin{array}{c}\text { IS (formerly Rhs -Rearrangement } \\
\text { hot spots- element) }\end{array}$ \\
\hline & ISEc1 & $5069737 . .5071026$ & AGACCAGT & GCATGTCA & $\begin{array}{c}\text { IS (formerly Rhs -Rearrangement } \\
\text { hot spots- element) }\end{array}$ \\
\hline \multirow{5}{*}{ IS6 } & IS26 & 4500893..4501712 & AAATCATG & ATATCAAG & \multirow{5}{*}{$\begin{array}{l}\text { Composite transposon harboring } \\
\text { the blateM-1в (two copies), cat } A 1, \\
\text { aph }\left(6^{\prime}\right)-i d, \text { aph }\left(3^{\prime \prime}\right)-i b, \text { sul } 2 \text {, and } \\
\text { tetD genes. }\end{array}$} \\
\hline & IS26 & $4503629 . .4504448$ & ATATCGGC & GGTAAATC & \\
\hline & IS26 & $4509192 . .4510011$ & CCGGCAAT & GTAAGCTG & \\
\hline & IS26 & $4513665 . .4514484$ & ACCATTTG & CGCTGCGG & \\
\hline & IS26 & $4515814 . .4516633$ & CAACAGGG & AAATCATG & \\
\hline \multirow{4}{*}{$\begin{array}{l}\text { IS200/ } \\
\text { IS605 }\end{array}$} & IS609 & $3978710 . .3980457$ & CTCA & ATAA & IS inserted within the yajI gene \\
\hline & IS609 & $4689442 . .4691189$ & TGTG & ATAA & $\begin{array}{l}\text { IS inserted within a intergenic } \\
\text { region }\end{array}$ \\
\hline & IS609 & $2110716 . .2111379$ & - & - & $\begin{array}{l}\text { IS (truncated) inserted within the } \\
\text { yedK gene }\end{array}$ \\
\hline & ISEc46 & $2191062 . .2192824$ & TCAT & CTAA & $\begin{array}{c}\text { IS inserted within a intergenic } \\
\text { region }\end{array}$ \\
\hline \multirow{2}{*}{$\begin{array}{l}\text { IS3 } \\
\text { ssgr } \\
\text { IS150 }\end{array}$} & IS1397 & $1214273 . .1215704$ & $\underline{\text { TCAA }}$ & $\underline{\text { TCAA }}$ & \multirow{2}{*}{$\begin{array}{l}\text { Single IS transposition within a } \\
\text { intergenic region } \\
\text { Single IS transposition within a } \\
\text { intergenic region }\end{array}$} \\
\hline & IS1397 & $1368490 . .1369921$ & $\underline{\text { TGGC }}$ & $\underline{\text { TGGC }}$ & \\
\hline
\end{tabular}


$\mathbf{7}$ de 11

\begin{tabular}{|c|c|c|c|c|c|}
\hline & IS150 & 259853..261295 & $\underline{\mathrm{AAG}}$ & $\underline{\mathrm{AAG}}$ & $\begin{array}{l}\text { Single IS transposition within a } \\
\text { intergenic region }\end{array}$ \\
\hline & IS150 & $2414087 . .2415529$ & GTT & GTT & $\begin{array}{l}\text { Single IS transposition. IS } \\
\text { inserted within a genomic island }\end{array}$ \\
\hline \multirow{4}{*}{$\begin{array}{l}\text { IS3_ssg } \\
\text { r_IS2 }\end{array}$} & IS2 & $937126 . .938456$ & GTGGT & TTGTC & $\begin{array}{l}\text { IS inserted within a putative } \\
\text { prophage }\end{array}$ \\
\hline & IS2 & 966497.. 967827 & CCGCC & ACGGT & $\begin{array}{l}\text { IS inserted within a putative } \\
\text { prophage }\end{array}$ \\
\hline & IS2 & $2027528 . .2028858$ & $\underline{\mathrm{CCTTT}}$ & CCTTT & $\begin{array}{l}\text { Single IS transposition. IS } \\
\text { inserted within a genomic island }\end{array}$ \\
\hline & IS2 & $4799912 . .4800262$ & AAAAC & - & $\begin{array}{l}\text { IS (truncated) inserted within a } \\
\text { putative prophage }\end{array}$ \\
\hline \multirow{3}{*}{ IS21 } & $\begin{array}{c}\text { IS100Ky } \\
\mathrm{p}\end{array}$ & 2015511..2017464 & $\underline{\text { TTTGT }}$ & $\underline{\text { TTTGT }}$ & $\begin{array}{c}\text { Single IS transposition. IS } \\
\text { inserted within a genomic island }\end{array}$ \\
\hline & $\begin{array}{l}\text { IS100Ky } \\
\mathrm{p}\end{array}$ & $3273162 . .3275115$ & GTGATAAC & GATAACAT & $\begin{array}{c}\text { IS inserted within a genomic } \\
\text { island }\end{array}$ \\
\hline & $\begin{array}{l}\text { IS100Ky } \\
\mathrm{p}\end{array}$ & $4582722 . .4584675$ & TTCAGATG & AGATGTAT & $\begin{array}{l}\text { IS inserted within a putative } \\
\text { prophage }\end{array}$ \\
\hline \multirow{3}{*}{ IS66 } & IS682 & $924827 . .926816$ & - & CATGTATC & $\begin{array}{l}\text { IS (truncated) inserted within a } \\
\text { putative prophage }\end{array}$ \\
\hline & ISEc22 & $923252 . .924827$ & ACAGAAGG & - & $\begin{array}{l}\text { IS (truncated) inserted within a } \\
\text { putative prophage }\end{array}$ \\
\hline & ISCro1 & $946022 . .948720$ & $\underline{\text { TTTTATCT }}$ & $\underline{\text { TTTTATCT }}$ & $\begin{array}{c}\text { Single IS transposition. IS } \\
\text { inserted within a putative } \\
\text { prophage }\end{array}$ \\
\hline \multirow{2}{*}{$\begin{array}{c}\text { IS3_Ssg } \\
\text { r_IS51 }\end{array}$} & IS629 & $570569 . .571878$ & $\underline{\mathrm{ATT}}$ & $\underline{\text { ATT }}$ & IS inserted within the $a c r F$ gene \\
\hline & IS1203 & $971759 . .973068$ & GATTACTG & GTAATATC & $\begin{array}{l}\text { IS inserted within a putative } \\
\text { prophage }\end{array}$ \\
\hline \multirow[b]{2}{*}{ ISL3 } & ISKox3 & $970324 . .971101$ & - & ATGTATCA & $\begin{array}{l}\text { IS (truncated) inserted within a } \\
\text { putative prophage }\end{array}$ \\
\hline & ISEc38 & $2022594 . .2024315$ & AAAAGT & ACTTTT & $\begin{array}{c}\text { Single IS transposition. IS } \\
\text { inserted within a genomic island } \\
\text { (inverted TSD) }\end{array}$ \\
\hline IS481 & ISErp1 & 891175.. 892368 & TATAATG & TATAATG & $\begin{array}{c}\text { Single IS transposition. IS } \\
\text { inserted within a putative } \\
\text { prophage }\end{array}$ \\
\hline IS30 & IS30D & $950498 . .951718$ & $\underline{\mathrm{GT}}$ & $\underline{\mathrm{GT}}$ & $\begin{array}{l}\text { Single IS transposition. IS } \\
\text { inserted within a putative } \\
\text { prophage }\end{array}$ \\
\hline IS4 & IS10A & $105162 . .106490$ & GGCCGAGC & GTGCTGAAC & $\begin{array}{l}\text { IS inserted into IS1-composite } \\
\text { transposon }\end{array}$ \\
\hline IS1380 & ISEcp1 & 326913..330008 & $\underline{\text { TTTA }}$ & $\underline{\text { TTTA }}$ & $\begin{array}{c}\text { Single IS transposition. IS } \\
\text { inserted within a hypothetical } \\
\text { gene }\end{array}$ \\
\hline IS110 & IS5075 & 1568363..1569689 & $\underline{\text { TT }}$ & $\underline{\text { TT }}$ & $\begin{array}{c}\text { Single IS transposition. IS } \\
\text { inserted within a hypothetical } \\
\text { gene }\end{array}$ \\
\hline
\end{tabular}


$\mathbf{8}$ de 11

109

110

111

112

113

114

115

116

117

118

119

120

121

122

123

124

125

126

127

128

129

130

131

132

133

134

135

136

137

138

139

140

141

142

143

144

145

146

147

148

149

150

\section{Discussion}

In this study, we perform the first report of an Escherichia coli isolate carrying the blaoxA-244 gene in Colombia and the American continent. These blaoxA-244-positive isolates are less frequent (or perhaps they circulate but are not detected) by their difficult detection and clonal dissemination. The multiresistant 28Eco12 isolate harboured an unique plasmid without resistance genes and genetically related to the plasmids p266917_2_02 (88\% coverage, 99\% identity, GenBank accession number CP026725.1), p1303_95 (91\% coverage, 99\% identity, GenBank accession number CP009168.1), p1 of Salmonella enterica strain ty3-243 (90\% coverage, 93\% identity, GenBank accession number LT905089.1), and pCRKP-59-KPC (89\% coverage, 94\% identity, GenBank accession number KX928752.1). All resistant genes were chromosomally located and mobilized by active composite transposons as such Tn6237, which has moved to different sites in the E. coli chromosome. In E. coli, the blaOXA-24 gene has been disseminated mainly by ST38 clone in Europe and Asia [3-7]. However, non-ST38 E. coli isolates are starting to appear in other countries, showing some genetic differences (Figure 1).

As it is known that ISs have an important impact on genetic variability, genome structure and function, and foreign DNA acquisition, we try to decipher the potential of the 28Eco12 isolate to capture and move more resistance genes through an analysis of the IS content and their TSD and flanking sequences patterns. Notably, this isolate has suffered at least 69 IS incorporations, showing a IS massive expansion process [12]; the ISs belonging family IS1 were the most active with fifteen copies, which four copies probably were recently mobilized as single transposition events (unique copies) and two mobilized as a composite transposon and responsible of the blaoxA244 gene integration (Table 1). In spite of finding five IS26 copies, only two of these were mobilized as a composite transposon and transported seven resistance genes. A study conducted by $\mathrm{He}$ et al reported the IS26 participation in the plasmid reorganization from clinical strains [13]. The high IS content found in this multiresistant E. coli isolate indicates a high likelihood to acquire more resistance genes.

Finally, our institution searched for the presence of the blaoxA-244 gene within other carbapenemresistant E. coli isolates from 2013 to the present day, but none were positive. Considering the time of the identification of the isolate, we believe that the $E$. coli isolate could have been acquired in the remittent institution, suggesting an inter-institution dissemination. No additional information could be obtained from the other institution.

\section{Materials and Methods}

The 28Eco12 isolate was identified from a retrospective study, conducted to characterize the molecular mechanisms in carbapenem-resistant Enterobacteriaceae isolates, which were recovered between 2013 and 2017 from a health institution in Bogotá, Colombia. The 28Eco12 isolate was recovered from a male patient in September 2013, who was transferred from another health institution in the same city. The patient had suffered multiple traumas cause by a fall from a height of 20 meters, and required treatment in the intensive care unit for eleven days. The patient was transferred to our institution, however, on the next day; the patient had fever, dysuria, urethral pain, leukocytosis, and urethral purulent secretion, suggesting a possible catheter-associated urinary tract infection. From a urine sample, the carbapenem-resistant Escherichia coli isolate 
9 de 11

151 28Eco12 was identified, which was also resistant to ampicillin/sulbactam, cefotaxime, ceftriaxone, 152 cefepime and aztreonam. The Hodge Test was positive and synergy and double-disc tests with 153 boronic acid and EDTA were negative. The patient was treated with meropenem ( 2 g every 8 hours) 154 and colistin (100 mg every 8 hours) and thirteen days later, he was discharged alive. No history of 155 travel by the patient or his parents was reported.

156 The complete genome sequence of the blaoxA-244-positive 28Eco12 isolate was obtained using the 157 PacBio RS II platform (Pacific Biosciences, USA) and assembled through the previously reported 158 procedure [14]. Briefly, sequencing reads were de novo assembled using the HGAP 3 protocol and 159 manually verified using BWA-MEM (Burrows-Wheeler Aligner with maximal exact matches)[15] 160 and Tablet v1.15.09.01[16]. Misassembled terminal repeat overlap sequences were identified with 161 Gepard (Genome Pair Rapid Dotter)[17] and trimmed manually. The genome was annotated using 162 Prokka v1.11[18], and the interesting regions were manually confirmed using BLASTn and BLASTp 163 and edited in Artemis [19]. The resistance gene arsenal was identified using ARIBA 164 (https://github.com/sanger-pathogens/ariba/wiki), ResFinder [20], CARD [21] and ARG-ANNOT 165 databases [22]. The insertion sequences (IS) were found using ISsaga (http://issaga.biotoul.fr/) and their flanking sequences were manually determined.

The study was approved by the ethics committee of the Shaio Clinic. The 28Eco12 complete genome sequenced in this study is available in the DDBJ/EMBL/GenBank public databases under the accession numbers CP038505.1 and CP038506.1.

\section{Conclusion}

Our results suggest that the introduction of the OXA-244-producing E. coli isolate was through clonal expansion of the ST38 pandemic clone. In addition, isolates producing OXA-244 could be circulating since 2013 on the American continent and have not been identified, perhaps due to their very low frequency, very difficult detection, and weakness in antimicrobial resistance surveillance programs in some countries (such as Colombia). It is necessary to strengthen the surveillance of last-line antibiotic resistance, and to move towards the implementation of molecular tools for the detection of resistance genes in clinical settings.

\section{Acknowledgments}

We gratefully acknowledge to the clinical laboratory personal for your technical assistance and to the Vice Chancellery for Research of El Bosque University (especially to Dr Miguel Otero for your invaluable support). This work was partially supported by the Departamento Administrativo de Ciencia, Tecnología e Innovación, Colciencias (grant number 1308-777-58007), Vice Chancellery for Research of El Bosque University (grant number PCI63-2014), and Fundacion-Clinica Shaio.

\section{Author Contributions}

JEP, IGBM and NVG designed research; IGMB, DFJM and ITM, identified the isolate; performed microbiological analysis, and interpreted the clinical characteristics of the patient; DA, RAMO, and ZLCR performed the molecular analysis and genome sequencing; DA, RAMO, JEP and ZLCR performed the paper. 
10 de 11

\section{Conflicts of Interest}

None to declare.

\section{References}

1. Tacconelli, E.; Carrara, E.; Savoldi, A.; Harbarth, S.; Mendelson, M.; Monnet, D.L.; Pulcini, C.; Kahlmeter, G.; Kluytmans, J.; Carmeli, Y., et al. Discovery, research, and development of new antibiotics: the WHO priority list of antibiotic-resistant bacteria and tuberculosis. Lancet Infect Dis 2018, 18, 318-327, doi:10.1016/S1473-3099(17)30753-3.

2. Oteo, J.; Hernandez, J.M.; Espasa, M.; Fleites, A.; Saez, D.; Bautista, V.; Perez-Vazquez, M.; FernandezGarcia, M.D.; Delgado-Iribarren, A.; Sanchez-Romero, I., et al. Emergence of OXA-48-producing Klebsiella pneumoniae and the novel carbapenemases OXA-244 and OXA-245 in Spain. J Antimicrob Chemother 2013, 68, 317-321, doi:10.1093/jac/dks383.

3. Valenza, G.; Nickel, S.; Pfeifer, Y.; Eller, C.; Krupa, E.; Lehner-Reindl, V.; Holler, C. Extended-spectrumbeta-lactamase-producing Escherichia coli as intestinal colonizers in the German community. Antimicrob Agents Chemother 2014, 58, 1228-1230, doi:10.1128/AAC.01993-13.

4. Potron, A.; Poirel, L.; Dortet, L.; Nordmann, P. Characterisation of OXA-244, a chromosomally-encoded OXA-48-like beta-lactamase from Escherichia coli. Int J Antimicrob Agents 2016, 47, 102-103, doi:10.1016/j.ijantimicag.2015.10.015.

5. Hoyos-Mallecot, Y.; Naas, T.; Bonnin, R.A.; Patino, R.; Glaser, P.; Fortineau, N.; Dortet, L. OXA-244Producing Escherichia coli Isolates, a Challenge for Clinical Microbiology Laboratories. Antimicrob Agents Chemother 2017, 61, doi:10.1128/AAC.00818-17.

6. Findlay, J.; Hopkins, K.L.; Loy, R.; Doumith, M.; Meunier, D.; Hill, R.; Pike, R.; Mustafa, N.; Livermore, D.M.; Woodford, N. OXA-48-like carbapenemases in the UK: an analysis of isolates and cases from 2007 to 2014. J Antimicrob Chemother 2017, 72, 1340-1349, doi:10.1093/jac/dkx012.

7. van Hattem, J.M.; Arcilla, M.S.; Bootsma, M.C.; van Genderen, P.J.; Goorhuis, A.; Grobusch, M.P.; Molhoek, N.; Oude Lashof, A.M.; Schultsz, C.; Stobberingh, E.E., et al. Prolonged carriage and potential onward transmission of carbapenemase-producing Enterobacteriaceae in Dutch travelers. Future Microbiol 2016, 11, 857-864, doi:10.2217/fmb.16.18.

8. Beyrouthy, R.; Robin, F.; Delmas, J.; Gibold, L.; Dalmasso, G.; Dabboussi, F.; Hamze, M.; Bonnet, R. IS1Rmediated plasticity of IncL/M plasmids leads to the insertion of bla OXA-48 into the Escherichia coli Chromosome. Antimicrob Agents Chemother 2014, 58, 3785-3790, doi:10.1128/AAC.02669-14.

9. Wirth, T.; Falush, D.; Lan, R.; Colles, F.; Mensa, P.; Wieler, L.H.; Karch, H.; Reeves, P.R.; Maiden, M.C.; Ochman, H., et al. Sex and virulence in Escherichia coli: an evolutionary perspective. Mol Microbiol 2006, 60, 1136-1151, doi:10.1111/j.1365-2958.2006.05172.x.

10. Brzuszkiewicz, E.; Bruggemann, H.; Liesegang, H.; Emmerth, M.; Olschlager, T.; Nagy, G.; Albermann, K.; Wagner, C.; Buchrieser, C.; Emody, L., et al. How to become a uropathogen: comparative genomic analysis of extraintestinal pathogenic Escherichia coli strains. Proc Natl Acad Sci U S A 2006, 103, 12879-12884, doi:10.1073/pnas.0603038103.

11. Wang, J.; Li, X.; Li, J.; Hurley, D.; Bai, X.; Yu, Z.; Cao, Y.; Wall, E.; Fanning, S.; Bai, L. Complete genetic analysis of a Salmonella enterica serovar Indiana isolate accompanying four plasmids carrying mcr-1, ESBL and other resistance genes in China. Vet Microbiol 2017, 210, 142-146, doi:10.1016/j.vetmic.2017.08.024.

12. Siguier, P.; Gourbeyre, E.; Chandler, M. Bacterial insertion sequences: their genomic impact and diversity. FEMS Microbiol Rev 2014, 38, 865-891, doi:10.1111/1574-6976.12067.

13. He, S.; Hickman, A.B.; Varani, A.M.; Siguier, P.; Chandler, M.; Dekker, J.P.; Dyda, F. Insertion Sequence IS26 Reorganizes Plasmids in Clinically Isolated Multidrug-Resistant Bacteria by Replicative Transposition. MBio 2015, 6, e00762, doi:10.1128/mBio.00762-15. 
239

240

241

242

243

244

245

246

247

248

249

250

251

252

253

254

255

256

257

258

259

260

261

262

14. Marquez-Ortiz, R.A.; Haggerty, L.; Olarte, N.; Duarte, C.; Garza-Ramos, U.; Silva-Sanchez, J.; Castro, B.E.; Sim, E.M.; Beltran, M.; Moncada, M.V., et al. Genomic Epidemiology of NDM-1-Encoding Plasmids in Latin American Clinical Isolates Reveals Insights into the Evolution of Multidrug Resistance. Genome Biol Evol 2017, 9, 1725-1741, doi:10.1093/gbe/evx115.

15. Li, H.; Durbin, R. Fast and accurate long-read alignment with Burrows-Wheeler transform. Bioinformatics 2010, 26, 589-595, doi:10.1093/bioinformatics/btp698.

16. Milne, I.; Stephen, G.; Bayer, M.; Cock, P.J.; Pritchard, L.; Cardle, L.; Shaw, P.D.; Marshall, D. Using Tablet for visual exploration of second-generation sequencing data. Brief Bioinform 2013, 14, 193-202, doi:10.1093/bib/bbs012.

17. Krumsiek, J.; Arnold, R.; Rattei, T. Gepard: a rapid and sensitive tool for creating dotplots on genome scale. Bioinformatics 2007, 23, 1026-1028, doi:10.1093/bioinformatics/btm039.

18. Seemann, T. Prokka: rapid prokaryotic genome annotation. Bioinformatics 2014, btu153.

19. Rutherford, K.; Parkhill, J.; Crook, J.; Horsnell, T.; Rice, P.; Rajandream, M.A.; Barrell, B. Artemis: sequence visualization and annotation. Bioinformatics 2000, 16, 944-945.

20. Zankari, E.; Hasman, H.; Cosentino, S.; Vestergaard, M.; Rasmussen, S.; Lund, O.; Aarestrup, F.M.; Larsen, M.V. Identification of acquired antimicrobial resistance genes. J Antimicrob Chemother 2012, 67, 2640-2644, doi:10.1093/jac/dks261.

21. McArthur, A.G.; Waglechner, N.; Nizam, F.; Yan, A.; Azad, M.A.; Baylay, A.J.; Bhullar, K.; Canova, M.J.; De Pascale, G.; Ejim, L., et al. The comprehensive antibiotic resistance database. Antimicrob Agents Chemother 2013, 57, 3348-3357, doi:10.1128/AAC.00419-13.

22. Gupta, S.K.; Padmanabhan, B.R.; Diene, S.M.; Lopez-Rojas, R.; Kempf, M.; Landraud, L.; Rolain, J.M. ARGANNOT, a new bioinformatic tool to discover antibiotic resistance genes in bacterial genomes. Antimicrob Agents Chemother 2014, 58, 212-220, doi:10.1128/AAC.01310-13. 